Transfusion Medicine
and Hemotherapy

\title{
Dengue Fever Virus (DENV)
}

\author{
Arbeitskreis Blut, Untergruppe «Bewertung Blutassoziierter Krankheitserreger»
}

\section{Introduction}

The name of the disease is said to be derived from the Portuguese word dengue which means fastidious or vain, which would describe the disturbed gait of an infected person suffering from muscle and bone pain (see also English: 'dandy'). Dengue virus and dengue haemorrhagic fever virus are synonyms. The dengue fever virus (DENV) is a member of the genus of the 53 flaviviruses and ranks among the 27 species of flavivirus which can be transmitted by mosquitoes. The significance of arboviruses was summarised in a paper published in 2004 [1]. This paper addresses the subject of whether DENV is one of the threatening viruses that might become significant in transfusion-medicine in the near future.

\section{Current Knowledge about the Pathogen}

Probably the oldest report consistent with the clinical course of DENV infection originates from China and dates back to the year 992 [2]. Historical reports on the so-called breakbone fever' date back more than 200 years, 1779 from Batavia, Indonesia, and Cairo, Egypt. The first dengue fever epidemic reported in an English-speaking country occurred in Philadelphia, USA, in 1780. Further cases followed in 1934 in Florida and in 1945 in New Orleans [3]. Major epidemics with haemorrhagic shock (dengue fever virus haemorrhagic shock syndrome - DHSS) occurred in Australia in 1897, in Greece in 1928, and in Formosa in 1921. The long intervals of 10-40 years between the epidemics in the same region were shortened due to the increasing trade after World War II. Besides, the rapid urbanization in South East Asia led to hyperendemics [2]. The propagation of Aedes aegypti and other Aedes species by modern means of transport and, in particular, shipping, led to a rapid spread of Aedes mosquitoes and at the same time DENV in all tropical regions of the world, so that the number of yearly infected people is assumed to be 50-100 million, that of hospitalisations around 500,000 , and that of infected patients with complications $250,000[4]$.

\section{Urban and Sylvatic Cycle}

Dengue fever is a typical zoonosis the host of which is essentially the monkey; however, after transmission to humans and the presence of the appropriate mosquito population, animal hosts are no longer required. All old-world and new-world monkeys are infectable with DENV and develop clinical signs of infection as well as viraemia. The significance of other animals as a reservoir for the proliferation of DENV is unclear. New-born mice can be infected with DENV, whereas adult guinea pigs, rabbits, hamsters, chickens, bamboo rats, and lizards cannot. Mice can only be infected in the lab using high doses. Neurotropism develops in these mice with increasing passage [5]. In Mexico, DENV antibodies were identified in 1 fruit-eating and 3 insect-eating bats, while DENV-2 (Dengue fever virus serotype 2; serotypes see section 1.1) was detected in 2 fruit-eating and 1 insect-eating bat. These bats were DENV-antibody negative [6].

Apart from Ae. aegypti and Ae. albopictus, DENV reproduces in Ae. africanus, Ae. leuteocephalus, Ae. opok, Ae. taylori, Ae. furcifer, and other species [7] so that other Aedes species, too, can serve as vectors.

The sylvatic cycle occurs in monkeys, and possibly also other smaller mammal species. Various Aedes species are involved in the cycle, which have become accustomed to the habitat of primates. Rain forests are the preferred reservoir in tropical regions. In West Africa, this also applies to gallery forests, so that epidemics also occur in savanna regions [7]. The sylvatic and urban cycles are interrelated via the mosquito vector [8]. The urban cycle is maintained by Ae. aegypti and Ae. albopictus strains which have become accustomed to the human habitat. They lay their eggs in small water reservoirs (sewage water, drinking water supplies, plastic waste), in which the larvae hatch after several days at temperatures $>25{ }^{\circ} \mathrm{C}$ and develop into mosquitoes. The vertical transmis-

\section{KARGER}

Fax +497614520714

Information@Karger.de

www.karger.com (c) 2011 S. Karger GmbH, Freiburg

Accessible online at:

www.karger.com/tmh
Prof. Dr. med. Rainer Seitz

Paul-Ehrlich-Institut

Paul-Ehrlich-Straße 51-59, 63225 Langen, Germany

Tel. +49 6103 77-2601, Fax -1250

Rainer.Seitz@pei.de 
sion of DENV from the mosquito to its offspring has been described. Mosquitoes become infected while sucking blood from DENV infected humans. DENV carrying mosquitoes infect humans, especially children who do not or not yet possess sufficient immunity. Thus, a cycle exists which could, as yet, not be interrupted by draining the breeding grounds of the mosquitoes in endemic regions.

\section{Transmission Pathway}

Aedes mosquitoes are essential natural vectors. Transmission by other mosquito species should be possible. Ticks are epidemiologically insignificant for transmission. Replication of the virus in the mosquito essentially depends on the external temperature. Increased temperatures elevate the virus concentration in the mosquito, thus increasing the transmission rate. However, mosquitoes die at very high temperatures and low humidity, which presents limits to transmissibility. Other factors determining the replication of the vector include relative humidity, rain, dryness, wind and storm, as well as conditions for deposition of eggs and larvae development [8].

\subsection{Characteristics of DENV}

\subsubsection{Virus}

DENV is one of the medically significant flaviviruses which also include other arboviruses such as West Nile Virus (WNV), Japanese Encephalitis Virus, Yellow Fever Virus, and Tick-Borne Encephalitis Virus. The enveloped DENV has a diameter of approximately $50 \mathrm{~nm}$ (fig. 1) with an electron-tight capsid of around $30 \mathrm{~nm}$ containing the singlestranded positive-sense RNA. The lipid envelope contains the E-protein (envelope; mw 50,000) which carries the essential antigenic determinants and the M-protein (membrane; mw 8,000) which is formed from the pre-M protein (prM; mw 18,000) by proteolytic cleavage [9]. The prM is required for adhesion and maturation of the virus on the membrane of the endoplasmatic reticulum. The E-protein forms dimers in the membrane and is flexible by rotation so that different epitope regions can be presented on the surface in mammal and mosquito cells. This flexibility, which is partly associated with formation of trimers, facilitates the fusion of virus envelope and cell membrane and can also be found in immature viruses as described for the DENV serotype 2 (DENV-2) [10]. Non-infectious empty virus particles, too, can be released by cells [11]. DENV can be replicated in many primary and permanent cell culture cells of e.g. humans, monkeys, hamsters, or mosquitoes [8].

\subsubsection{DENV Serotypes 1 to 4}

DENV is distinguished in 4 serotypes, DENV-1 to 4 , which are further subdivided into genotypes. Among the serotypes, DENV-1 and 3 are more closely related to each other than to DENV-2 and finally DENV-4.
Fig. 1. Transmission electron microscopic picture of DENV, with a size of around $30 \mathrm{~nm}$ in diameter. The thick stained round envelope may be seen. The photograph is courtesy of Dr Regine Allwin, Institute of Medical Virology, University Frankfurt/M.

\section{DENV-1}

Genotype 1 of DENV-1 seems to be less virulent for humans.

\section{$D E N V-2$}

Four pathogenic genotypes of DENV-2 circulate: the sylvatic West-African, American, South-East Asian, and MalayanIndian DENV-2. DENV-2 is highly pathogenic for humans.

\section{$D E N V-3$}

DENV-3 is subdivided into 4 genotypes. The American genotype has the lowest epidemiological propagation potential, since the virus replicates in mosquitoes only to a minor extent [12]. The South-East Asian and Indian genotypes of DENV-3 were responsible for the major epidemics which occurred on both subcontinents and Sri Lanka in 1989/90.

\section{$D E N V-4$}

Three genotypes of DENV-4 are known of which the Malayan genotype has the lowest pathogenic significance, whereas the 2 other genotypes have also spread in the 2 Americas. Six amino acid exchanges in the prM, E, NS4B, or NS5 regions can be sufficient to cause a change in virulence [13]. In the E-protein, intramolecular links between the amino acids 204Arg, 261His, and $257 \mathrm{Glu}$ in mutants are responsible for the change in virulence. The age of the common precursor, from which the currently known 4 DENV serotypes developed in primates, is calculated as roughly 500 years (range $100-1,500$ years) $[4,7]$. The age determination is based on the calculation of mutations in the nucleic acid sequence of different DENV strains isolated at known time points at particular locations. The calculation performed raises the question whether the mutations found all developed in humans, in animals, or by recombination. If the calculation is correct, DENV has a large adaptation potential for future epidemics and further hosts. Various DENV can form intragenotypic variants [8], which extends the variability of the DENV strains.

\subsubsection{Virus Receptor and Replication}

Adherence of DENV to the host cell, usually to macrophages or dendritic cells, partly also endothelial cells, occurs via the C-type lectin, DC-SIGN (ICAM-3) and via the carbohydrate chain of the E-protein [14]. Other membrane proteins such as 
Fig. 2. Scheme of the genome of DENV on top with the 3 structural proteins coded from the $5^{\prime}$ genome on the left and the location of the 4 enzymes in the non-structural coding 3 ' region right.

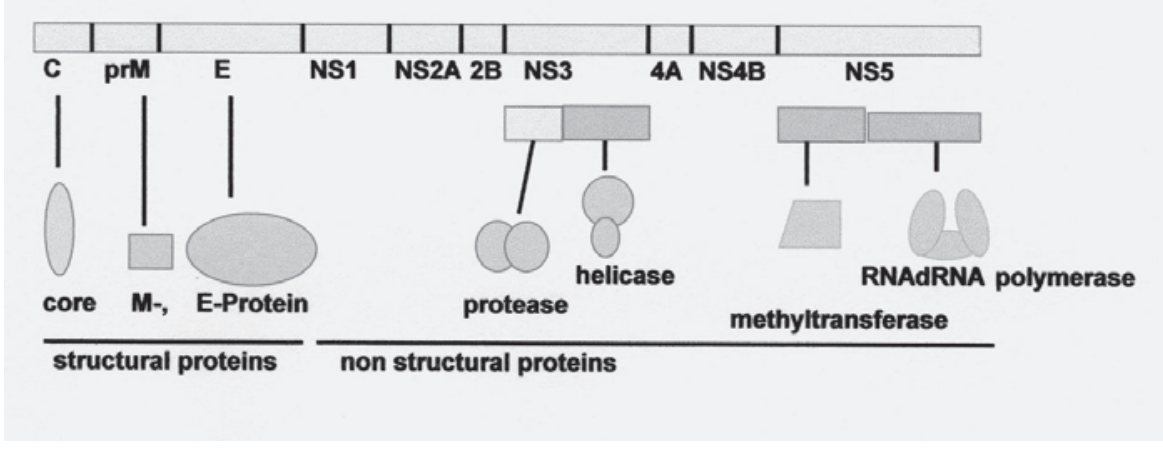

Fig. 3. Exanthema caused by DENV in a 23-year-old woman, after the 10th day of mosquito bite in India. The centre of the dark red area in the lower part of the lower leg is the location of the mosquito bite (picture: Guertler, 2005).

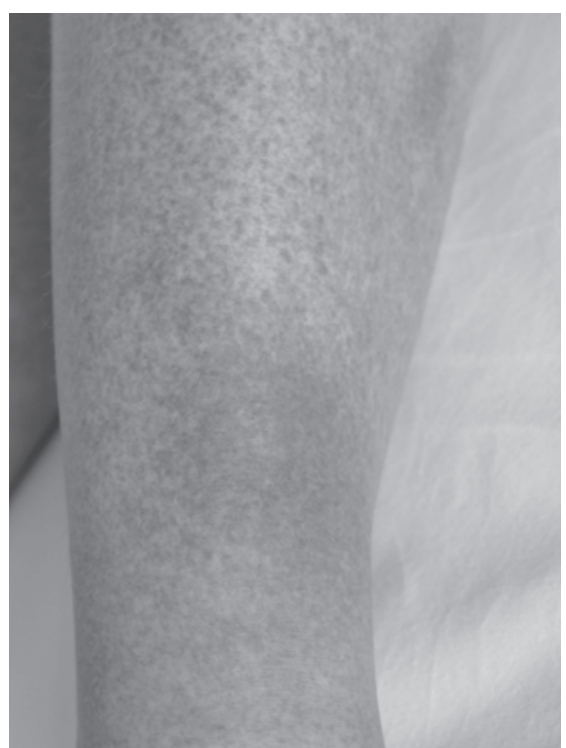

$\alpha \beta$-integrin, GRP78, and CD14 facilitate phagocytosis of the DENV particles. In addition, heparan sulphate is involved in the adhesion [15]. The integrin-binding site in the E-protein domain III concerns the RGD (arginine, glycine, aspartic acid) motive of encephalitic flaviviruses [16] which is also present in other viruses, such as rhinoviruses. DENV-1 and DENV-2 are fixed to the laminin receptor GRP78 [17] which is also expressed on liver cells. DENV is absorbed via the immunoglobulins bound to the particle (immunophagocytosis) on Fc-receptor-carrying cells [18]. The capsid is released from the phagocytosed virus in the phagosom at low $\mathrm{pH}$. During reshaping of the virus envelope, the E-protein dimers dissociate into monomers and then form trimers. A high cholesterol content of the membrane accelerates fusion [19]. The 2 heat shock proteins, 70 and 90, accelerate the uptake of DENV in cholesterol-rich membranes [20]. DENV replicates in cytoplasm without cell nucleus involvement. Maturation occurs on the endoplasmatic reticulum. The immature virus buds into the endoplasmatic reticulum where it envelopes itself with lipid membrane of the cell, and is then transported in the tubes of the endoplasmatic reticulum to the cell membrane, where it is released in its mature form [21].

\subsubsection{Genome}

The genome of DENV is typical of flaviviruses with a 5' nonencoding region (NCR) and 3' UTR (untranslated region) on the flanks, between which the regions of core, prM, E, and the nonstructural proteins are located. The genes for the nonstructural proteins encode the proteins NS1, NS2A and NS2B, with NS3 consisting of protease and helicase, NS4B and NS5 containing methyltransferase and the RNA-dependent RNA polymerase (fig. 2). The 10 proteins are cleaved from the polyprotein precursor protein [9]. The methyltransferase, which influences the 5 '-cap structure, can be inhibited by ribavirin $[22,23]$.

\subsection{Infection and Infectious Disease}

Transmission usually occurs via a mosquito bite of the Aedes species. After an incubation period of typically 2-7 days, the DENV-specific symptoms occur, which include sudden high fever, head and limb ache, retrobulbar pain, and severe muscle pain. The latter was the reason why the disease is also called break-bone fever. After a few days, a maculopapular exanthema (fig. 3) manifests itself beginning on the torso and spreading out into the extremities and the face. Petechiae may also occur, in particular, at the site of the mosquito bite. In the first 2 weeks, infected individuals show extreme pathological signs, which subside 1 week after occurrence of the exanthema. The fever course is typically biphasic (saddle-shaped) with the second peak starting as soon as the exanthema appears. Fever of up to $41^{\circ} \mathrm{C}$ is not unusual (fig. 4). The diagnosis is confirmed by detection of $\operatorname{IgM}$ and $\operatorname{IgG}$ antibodies, and viraemia is confirmed via nucleic acid testing (NAT; see section 1.4). The following diseases are distinguished, depending on virulence of DENV and clinical symptoms: Dengue fever, Dengue haemorrhagic fever (DHF), and Dengue shock syndrome (DSS). DHF was described in the Philippines in 1950. It occurred above all in children who had probably previously 


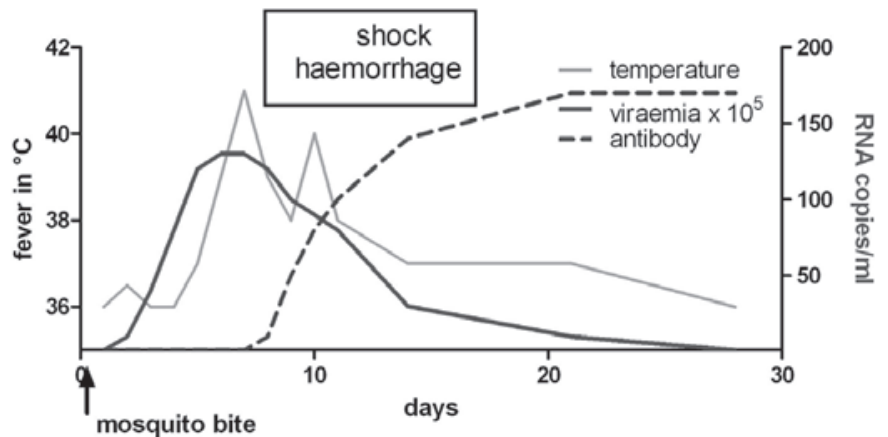

Fig. 4. Scheme of the course of fever, viraemia, and antibody after primary infection with DENV. Temperature of fever is indicated at the left $\mathrm{Y}$-axis, the viraemia is given as cop/ml blood on the right $\mathrm{Y}$-axis.

been infected by a different DENV serotype. DHF can evolve into DSS, which seldomly occurs with first-time infections. With DHF, only minor bleeding events with manifestation of petechiae may be present, but it may also display severe pathological signs with transition to DSS or DHF/DSS, combined with a drop in blood pressure, cyanosis, hepatomegaly, and partly gastrointestinal bleeding. DSS lasts 1-2 days and either takes a lethal course or leads to complete recovery.

\subsubsection{Pathogenesis}

Essentially, monocytes and macrophages are involved in the pathogenic effect of DENV. At least a part of the DENV in the macrophages is destroyed after phagocytosis by these cells. If antibodies are present which do not sufficiently neutralize the DENV, a part of the viruses is ingested by macrophages via immunephagocytosis, and replicates in these cells. Other cells which carry the Fc gamma receptor are also infected. When the virus is released, immune complexes are formed which activate the complement system and lead to damage of the capillaries with haemorrhage if the complexes adhere to endothelial cells. DSS manifests itself depending on the degree of intravasal activation of the coagulation cascade and damage to the endothelial layer. The damage to the cells is aggravated further by the activation of different cytokine cascades (known as cytokine storm) and by NF-kappa B and the cell death thus induced. In a study involving hospitalised patients with DENV-3 in Brazil, 25\% of the $>14$-year-olds showed signs of capillary damage, partly with shock and thrombocytopenia $<50,000 / \mathrm{mm}^{3}$ as well as 3-fold increased aspartate aminotransferase (AST) levels [24]. One of the complications of DHF is Dengue maculopathy which occurs in around $10 \%$ of the diseased individuals. The cause is retinal vasculopathy with minor up to total loss of vision [25]. DENV can be detected in the cerebrospinal fluid of patients with encephalitis, which indicates that DENV - like all other flaviviruses - can also be neuropathogenic [26, 27].

Development of DHF and DSS depends on the following factors [28]: i) Antibodies: Binding but not sufficiently neutralising antibodies, known as enhancing antibodies. They are present especially if an infection with another DENV serotype had occurred before, or, for instance, in children, if residual maternal antibodies are present. Antibody enhancement is favoured by precursor membrane (prM) antibodies, which are cross-reactive between the 4 serotypes but not neutralising [29].

ii) Age: Complications hardly occur after the age of 12 years. Repeated exposure to all DENV serotypes in endemic areas is probably the reason for having established sufficient immunity by then.

iii) Ethnical background: Caucasians and Asians have more severe courses of the disease than Africans.

iv) State of nutrition: A good state of nutrition improves the body's defence mechanisms.

v) DENV infection sequence: If DENV-1 is followed by DENV-2, severe courses occur more frequently than if for instance DENV-4 is followed by DENV-2.

vi) DENV serotype: DENV-2 seems to show the highest virulence. As described in 1.1, major differences in virulence also exist within one DENV serotype.

For $1 \%$ of the patients with DFH or DSS, the infection is lethal. The lab parameters of the DENV infection are thrombocytopenia, low haemoglobin, haemolysis parameters, and an increase in transaminases with liver cell decay. Timedependent IgM and IgG antibodies can also be detected. The NAT on DENV-RNA is positive with the occurrence of fever. No clinical symptoms occur in DENV-infected rhesus monkeys [30]. This is a possible indication that the adaptation between DENV and rhesus monkey occurred a very long time ago. In other primates, DENV causes the typical clinical symptoms but no neurological disorders. Mice develop immunity after a short period of time (see section 1 ), so that they are not a suitable animal model for virulence assays.

\subsection{Epidemiology}

The presence of the 4 DENV serotypes has been described worldwide in tropical, partly also subtropical, zones since 2006. Endemic areas of DENV essentially correspond to the areas of geographical distribution of the Aedes mosquito and the lower primates that live in these areas (fig. 5) ([31]; WHO: http://gamapserver.who.int/mapLibrary/). DENV regions include Asia, Oceania, Australia, Africa, as well as Central and South America. Since 1990, Dengue fever has also been endemic in Argentina, Nepal, Mexico, and Hawaii. In 2008/2009, a major epidemic occurred in Bolivia with more than 7,250 cases. Another typical characteristic of Dengue fever is that it occurs in cycles, which is due to the distribution of variant serotypes, the infection rate of mosquitoes, and immunity in lower primates and humans. In zones with an urban cycle, the immune status of humans, the ambient temperature, and the 


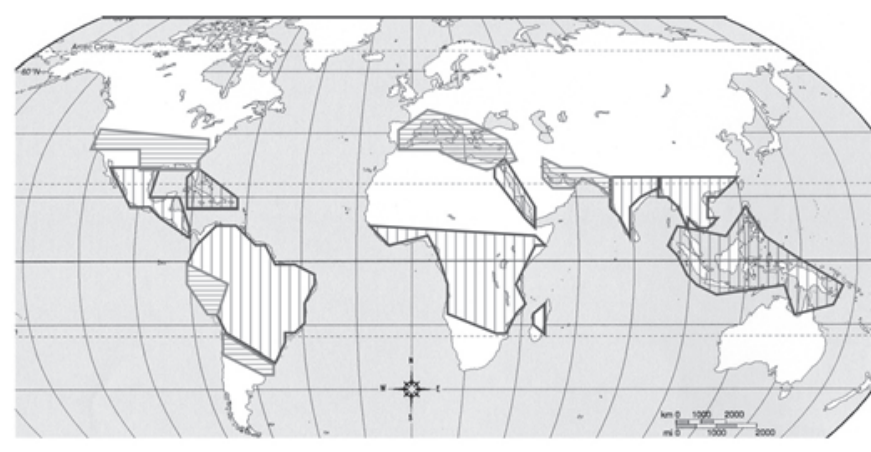

$\square$ Areas with epidemics and high risk of dengue virus transmission and monkey population Areas where Aedes aegyptii and Aedes albopictus is prevalent, but not dengue virus

Fig. 5. Aedes albopictus. Epidemiology of DENV in the vertically hatched area, closely linked to the presence and breeding places of various Aedes mosquitos and human or primate reservoirs, while the presence of Aedes mosquitos without DENV transmission is more extended (horizontally hatched areas). Data represent the status in 2009.

number of mosquito breeding grounds are the factors determining the frequency of the epidemic. The period of crossprotection between the different DENV serotypes sometimes seems to be less than 12 weeks [32].

The mosquito eradication programme designed to combat malaria also contributed to reduce the distribution of Aedes, which for instance in 1930 was widespread in many South American countries. By 1970, its geographic area distribution was reduced to a quarter. In the southern part of South America, it was even eradicated. Since 1980, with the termination of the mosquito eradication programme, Aedes has spread again, and its distribution is now comparable with the levels of 1930. The distribution of the DENV serotypes fluctuates over time, which was studied in Tahlan, Thailand over a period of 30 years. As from the mid-1980s, DENV-1 replaced DENV-2 in that region. As from the mid-1990s, the prevalence of DENV-1 decreased again, while that of DENV-4 increased [33]. High morbidity figures were reported from Brazil, Bolivia, the West Indies, and Birma (Myanmar) during the 2008/2009 season.

Among 2,260 German tourists studied between 1996 and 2004, 4.7\% had DENV-IgM antibodies pointing to an infection, which had taken its course only very recently, and $1.1 \%$ had DENV antibodies without any clinical record of fever [34]. During examinations on differential diagnostics of malaria at St. Gallen, Switzerland, 3 out of 38 tourists (8\%) were found to have DENV-IgM and IgG antibodies pointing to an infection with an acute course, and in another 4 of the 38 (10\%) travellers, only DENV-IgG was found, which was interpreted as resolved infection [35]. Assuming sufficient specificity of DENV-antibody ELISA, these results indicate that a DENV infection can also take an asymptomatic course.

During the DENV epidemic in Bangladesh in 2000, 225 hospitalised patients with fever were examined in Dhaka, out of whom $55(24 \%)$ had DENV antibodies, while in the control group of 184 blood donors, only $1(0.5 \%)$ was antibody-positive [36].

The area of occurrence of the Dengue fever is related to the distribution of Ae. aegypti. The extent to which a permanent spreading of the Aedes mosquito continues with the increasing global warming should be further observed [37]. Other epidemiologically relevant mosquitoes for the transmission of DENV include Ae. albopictus and Ae. polynesiensi. Ae. albopictus has in the meantime spread to the entire Mediterranean region and Western Europe, as shown in studies from Spain, France, Italy, Croatia, Belgium, and the Netherlands [38-41]. However, flavivirus RNA could so far not be detected in 964 Aedes mosquitoes from Italy [40] and 596 from the Netherlands [42]. In September 2010, the first nonunexpected, autochthonous DENV infection was reported in a 64-year-old man in Nice, which was followed by a second case only a few days later. Both viruses were DENV-2 and showed the same nucleic acid sequence [43]. Furthermore, a DENV infection was confirmed in a German person, which had been acquired in Croatia. The nucleic acid sequence of the DENV acquired in Croatia diverged from the DENV found in the French cases [44].

The occurrence of Dengue fever could be reduced by the eradication of the vector. The prevention of the spreading of the mosquito fails due to the fact that stagnant water is available for depositing the egg in the vicinity of human accommodation worldwide (e.g. non-degradable plastic containers filled with water or end-of-life tyres). Further factors favouring the occurrence of DENV infections include the resistance of mosquitoes to insecticides, a shortage of ventilators and mosquito nets for the prevention of mosquito bites among the poor population, and the non-availability of a vaccine.

Pursuant to Section 7 German Infection Protection Act (Infektionsschutzgesetz, IfSG), haemorrhagic fever must be reported by name (Section 7.47 ), which means that this obligation also refers to the direct and indirect detection of DENV. Imported DENV infections are so far the only source of DENV in Central Europe. In Austria, altogether 93 cases were verified between 1990 and 2005. A total of $43 \%$ of the cases displayed exanthema and $22 \%$ lymphadenopathy, and in addition thrombocytopenia, leukopenia and an increase in transaminases were noted. None of the infections were of lethal outcome [45]. In France, around 12-28 infections were registered per month between 2001 and 2006. This figure was higher in 2001/2002, since an epidemic took place in the French overseas Départements (West-Indies and Guyana) [46]. In Sweden, 30-60 cases became known per annum between 2004 and 2008. About 75\% of these cases had become infected in South-East Asia, most of them in Thailand. The tendency of importing a DENV infection increased with 17 cases alone in January 2009 [47]. The numbers of DENV cases in Germany, which became known based on the obligation to report them, were between 60 and more than 400 per annum. They are summarised in table 1. Autochthonous 
Table 1. Reported DENV cases in Germany (RKI Epidemiologisches Bulletin, 27/2007, completed)

\begin{tabular}{ll}
\hline Year & Cases reported, n \\
\hline 2001 & 60 \\
2002 & 213 \\
2003 & 131 \\
2004 & 121 \\
2005 & 144 \\
2006 & 175 \\
2007 & 264 \\
2008 & 273 \\
2009 & 298 \\
2010 & 595 \\
2011 & 110 (up to May) \\
\hline
\end{tabular}

transmissions of DENV by mosquito bite have so far not been reported in Germany, but they could occur in the same way as they did in France and Croatia.

\subsection{Detection Methods and Their Significance}

The following commercial tests are available for virus detection using NAT and antibody diagnostics.

\subsubsection{Antibody Detection}

In serological diagnostics, the pronounced cross-reactivity between the different flaviviruses, leading to limited specificity, must be taken into account [1]. First IgM antibodies are detectable about 1 week after the occurrence of clinical symptoms, i.e. around 2 weeks after infection by the mosquito bite. The IgM tests have so far not been sufficiently validated, and tend to produce false-positive results [34]. For IgM tests, the sensitivity values are given between $21-99 \%$ and specificity values between 77-99\% [48]. The rate of false-positive results is, among other factors, influenced by concomitant malaria and previous DENV infections [48]. A neutralisation test can be used for the differentiation of further flavivirus species [49]. Domains II and III of the envelope E-protein are epitopes suitable for the specific detection of DENV-2 [50, 51]. NAT polymerase chain reaction (PCR) is the better method to identify DENV double infections than ELISA [52]. Antibodies and double infections can also be tested via capillary blood absorbed on filter paper (dry blood spot) [53]. ELISA results should be confirmed by means of Western blot with purified virus or a neutralisation test. Out of the stained bands in the Western blot, those of the NS1, E, and prM proteins are the most informative ones [54].

\subsubsection{Antigen Detection}

NS1 protein is secreted from infected cells in large quantities, and is therefore suitable for antigen detection. For this purpose, an ELISA is available which contains monoclonal antibodies against NS1 protein [55]. Another commercial test uses NS1 in a capture ELISA and reaches a sensitivity of $90 \%$ at a specificity of $99.5 \%$ [56]. A similarly configured test yielded a sensitivity of $63 \%$ and a specificity of $98 \%$ in 253 samples in Thailand [57]. Commercial tests are available which recognize the 4 DENV serotypes with a sensitivity of $77 \%$ and a specificity of $98 \%$ [58]. The NS1 antigen test is usually only positive during the first DENV infection [59]. The NS1 antigen test can only be interpreted together with the DENV IgM and IgG results [58].

\subsubsection{Virus Detection}

At the time of primary infection, increase in temperature and detectability of the virus by means of NAT coincide. Viraemia can last up to 1 or 2 weeks. During secondary infection, the virus can be detectable in the blood 2-3 days before the rise in temperature. The viraemia in this case usually only persists 2-5 days [4]. Mosquito cells extracted from Ae. albopictus are suitable for virus cultivation [60-62]. Further cells are Vero cells or, for example, primary human pulmonary epithelial cells and pulmonary carcinoma cells [63]. DENV 2 can be replicated in mouse macrophages J774 [64]. DENV influences the cell metabolism if cultivated in HepG2 cells [65]. All 4 DENV serotypes produced viruses with high genetic stability after transfection of Vero cells or MRC5 cells with a c-DNA clone [66].

\subsubsection{Genome Detection}

Different papers describe the detection of DENV genome by real time(RT)-PCR $[67,68]$. Suitable primer binding sites are located in the core and envelope section. A Taqman RT-PCR in the NS5 region has been developed in order to detect all DENV serotypes; the test showed a sensitivity of $90 \%$ and a specificity of $100 \%$ in samples from Malaysia [69]. RNA could be detected in $89 \%$ of the blood samples of patients from Puerto Rico with clinically detectable acute DENV infection using the transcription mediated amplification (TMA) test [70]. High sensitivity can also be achieved if the 3' UTR region is used as target sequence [71]. DENV serotypes can be differentiated by nested PCR by amplifying the core region (sensitivity $76 \%$, specificity $100 \%$ ) at a sensitivity for the detection of DENV-1 of 10 copies, and for DENV-2 to 4 of 100 copies $[72,73]$. Finally, a test has been developed in which EDTA whole blood was used as starting material for RT-PCR [74]. After RT-PCR amplification, different flaviviruses can be identified by mass spectrometry [75]. The concentration of DENV virus in the blood correlates with the severity of the disease. For values $>10^{6}$ genome equivalents $/ \mathrm{ml}$, there is a risk of DHF development of approximately $90 \%$ [76]. Values of $10^{9}$ genome equivalents/ $\mathrm{ml}$ can be found in plasma [76, 77].

\section{Blood and Plasma Donors}

The risk of transmission of DENV via the blood is still rated as low, even though 2 cases have been reported from Hong 
Kong and Singapore [78]. In Honduras, Brazil, and Australia, 13,372 blood donations have been tested using the TMA test, among which 8 from Honduras and 1 from Brazil contained DENV-RNA [79]. Among the 16,521 samples from Puerto Rico drawn after the peak of the DENV epidemic of 2005, 12 were DENV-RNA positive in the TMA test; 4 of 5 could be confirmed by PCR [80]. Model calculations have been developed for the possibility of transmission of arboviruses [81].

\subsection{Prevalence and Incidence in Donor Populations}

In assessing incidence and prevalence, a difference must be made between data from endemic and those from nonendemic regions. In endemic regions, incidences of $0.1 \%$ have been found when blood was collected before the occurrence of a febrile phase [79, 80]. Among 683 blood donors and 492 pregnant women in Burkina Faso, 26\% of the individuals in the rural areas had antibodies against DENV compared with $37 \%$ in the capital (Ouagadougou) [82]. As mentioned in section 1.3 Epidemiology, 1 blood donor (0.54\%) with DENV antibody was found among 184 blood donors in Dhaka, Bangladesh [36]. Among German tourists in Berlin returning from their travels with acute fever and diarrhoea, $4-5 \%$ had antibodies against DENV [34]. Among 71 travellers in Berlin returning from tropical countries with fever and typical clinical signs of DENV infection, 55 (77.5\%) had DENV antibodies during the period from 1993-2001 [83]. If figures are used from Berlin (4-5\%) and Frankfurt (9\%) [84], an incidence of $<1$ in 10,000 can be calculated for Germany. In the TropNetEurop Study of 2002, 294 patients with DENV could be recorded in around 51,000 travellers per annum for the years 1999-2001, out of whom 7 were recorded to have DHF [85]. This corresponds to an incidence of around $0.2 \%$ for this group of travellers. Most of these infections were acquired in India and Thailand, followed by Brazil, the Caribbean Islands, and Mexico. Among development aid volunteers returning to Germany, 6.4\% were DENV antibody positive, with the highest number of infections acquired in Thailand, followed by Benin and Burkina Faso [86].

\subsection{Definition of Exclusion Criteria}

During a DENV infection, a viraemic phase can be observed approximately 1 week after a mosquito bite before the onset of symptoms. This phase lasts 1 to possibly 2-3 weeks (fig. 4). Primary infection always takes a course of high fever and other signs of acute inflammation [4]. If such symptoms occur, blood donors are deferred from donation for 4 weeks, this measure will as well avoid DENV transmission. A second DENV infection or, possibly, a reactivation of the DENV infection can take an asymptomatic to lethal course, i.e. a short-term viraemic phase may not be detected in clinically healthy blood donors. A major part of the endemic areas of Dengue fever overlaps with those where malaria is endemic. A possibly acquired DENV infection should be overcome after deferral based on malaria during a stay in these endemic areas for 6 months. From that point of view, exclusion criteria for the prevention of transfusionassociated transmission of malaria are also effective for DENV. A chronic DENV infection with the presence of the virus of more than 6 months, as was described for West Nile fever, has so far not been reported for a DENV infection [87]. Australia, where DENV is endemic in the north of the country, has minimised the risk of transmission by blood through epidemiological surveillance and donor selection, even though DENV screening tests have so far not been used [88].

\subsection{Donor Testing and Significance}

Based on the epidemiological situation, the testing of donors or donations for DENV is currently not required in Germany.

\subsection{Donor Interviews}

Donors are interviewed about their travels to tropical regions and general symptoms of inflammation as well as fever. They are not specifically interviewed about DENV symptoms, since, based on the epidemiological data situation, this is not required to prevent DENV transmissions.

\subsection{Donor Information and Counselling}

Specific counselling on Dengue fever is available in the infectious diseases centres or institutes for tropical medicine. For blood donation centres, this is currently not necessary.

\section{Recipients}

\subsection{Prevalence and Incidence of Blood-Associated Infections in Recipient Populations}

If recipients in Germany have not been in DENV endemic regions, they do not have antibodies against DENV and are therefore susceptible to DENV infection. Recipients from endemic regions might have acquired antibodies, depending on the region and the prevalence of DENV. These antibodies can be neutralising, cross-reactive, or enhancing, depending on the serotype and infection course. 


\subsection{Immune Status (Resistance, Existing Immunity, Immune Response, Age, Exogenous Factors)}

The acute DENV infection is normally overcome in 2-3 weeks. The patient's age and an iatrogenic immune suppression may slow down the process of recovery. The so-called immune enhancement, i.e. enhanced pathogenesis by insufficient immune defence has so far only been reported in children in endemic regions. Specific antiviral treatment is not available, so that the course of recovery cannot be influenced. Natural resistance against DENV is not known, and is not expected either, since several receptors are present for the entry of DENV into the cell (see section 1.1 Characteristics of DENV).

\subsection{Severity and Course of the Disease}

In a quarter of infected individuals, the DENV infection displays a severe course which leads to hospitalisation in $1 \%$ due to the general symptoms with high fever [89]. Five to $10 \%$ of the hospitalised individuals develop DHF, and around 1\% develop DSS. The death rate is below $1 \%$ of the hospitalised individuals [85]. Laboratory parameters for the severity of the infection include the degree of thrombocytopenia and the frequency of the elevation of transaminases [89]. Since capillary damage with DHF is partly viral, partly autoimmunological, therapeutic intervention designed to alleviate the symptoms cannot be specific. Complications of the DENV infection are partly due to involvement of the nervous system [90, 25], partly due to haemorrhage [91], and very frequently due to myositis [92]. A specific hyperimmunoglobulin is not available. If it would be available, it should have to be used on a serotype-specific basis (see section 3.4 Therapy).

\subsection{Therapy and Prophylaxis}

\subsubsection{Therapy}

A specific therapeutic product against DENV or a different flavivirus is not available. Treatment occurs on a symptomatic basis by reducing the fever and supplying the patient with liquid. In vitro, iminosugars, which inhibit glucosidase I and II on the endoplasmatic reticulum, show antiviral activity against DENV, WNV, and bovine viral diarrhoea virus (BVDV) [93]. Receptor blockade is possible in vitro via the zosteric acid (p-sulfoxy-cinnamin acid) [94]. As is the case with hepatitis C virus, the inhibition of the NS3 protease reduces polyprotein cleavage which is an essential step in DENV replication [95]. Experimental immunoglobulin therapy involves administration of antibodies, including monoclonal antibodies, specifically directed against a DENV serotype, by which the pathogenic effect of DENV can be stopped in the mouse [96]. A cross-neutralising monoclonal antibody was generated which binds to the ED3 domain of the E-protein and neutralises all
4 DENV serotypes [97]. However, an 'immune enhancement' can also be created by administering monoclonal antibodies in vivo and in vitro on K562 cells [98].

\subsubsection{Prophylaxis}

Avoiding mosquito bites is the most effective prophylaxis, also against DENV infection, similar to other infectious agents transmitted by mosquitoes. In many regions where DENV is transmitted, other arboviruses, plasmodia, and microfilaria, can also be transmitted by mosquitoes. Another prophylactic activity is the elimination of the mosquitoes' breeding grounds as mentioned above.

\subsubsection{Vaccination}

A vaccine against DENV is not yet available. Developing such a vaccine is characterised by 2 problems: the first one involves defining suitable cross-neutralising epitopes for all DENV serotypes, and the second one involves conferring vaccine-induced immunity to such a level and long-lasting synthesis that no 'immune enhancement' is created during exposure with any given DENV serotype. An overview of the possibility of a vaccination against DENV for travellers was published in 2008 [99]. Rhesus monkeys can be partly protected by a tetravalent vaccine in which the E-protein is integrated into an adenovirus vector. Vaccinated animals develop low viraemia following exposure [100]. Depending on the serotype, the immune response in rhesus monkeys can be $70-100 \%$ and reach a protective effect of 50-80\% [101]. An enhancement of the T-cell immune response has been reached by a polytope vaccine [102]. Recombinant attenuated virus with a deletion in the 3' UTR region was able after 4 vaccine shots to protect rhesus monkeys against DENV-2 [103]. Balb/c mice could be protected against DENV infection by means of an NS1 protein containing a DNA vaccine [104]. A vaccine with attenuated DENV which can no longer enter the cell has also been produced as a potential vaccine against DENV [105]. Recombinant tetravalent DENV vaccine, produced in drosophila cells, confers protective immunity in mice and monkeys [106].

\subsection{Transmissibility}

\subsubsection{Blood Transfusion}

So far 2 papers report DENV transmission by blood transfusion: 1 paper has been published reporting on 3 transfusionassociated DENV transmissions in Singapore in 2008 [107]. The donor was a 52-year-old man; the 3 recipients of red blood cells, fresh frozen plasma, and platelets all had signs of a DENV infection. The predominant symptom was myalgia. Another transmission by blood transfusion was reported from Hong Kong [108]. Among 126 hospitalised cases with DENV infection between 1998 and 2005, the latter was the only case in Hong Kong, which occurred by blood transfusion. The risk of a transmission via the blood outside the endemic regions 
has been estimated as very low in the USA [78, 81]. Regarding transplants, up to now, 1 DENV transmission with development of DHF has been reported in a recipient after kidney transplantation in 2005 [109].

\subsubsection{Needle Stick Injury}

Small quantities of blood as in the 4 described transmissions by needle stick injury are sufficient for DENV transmission, if the index patient is in the acute viraemic phase [110-113]. Clinical signs of infection can be observed after about 1 week. The exanthema can be seen after approximately 2 weeks, and after approximately 3 weeks, the symptoms of the DENV infection will have subsided. No haemorrhage occurred in any of the primary infections caused by a needle stick.

\subsection{Frequency of Administration, Type and Amount of Blood Products}

A transmission of DENV by blood or blood products has so far not been reported in Germany. The deferral of the donors 6 months after a stay in a tropical region because of the risk of malaria on the one hand and the deferral for 4 weeks following febrile diseases on the other minimize the risk of transmission. The low number of transfusion-associated DENV infections worldwide does not allow an estimation of the transmission risk based on the frequency of the applications and the quantity administered.

\section{Blood Products}

\subsection{Infectious Virus Load of the Starting Material and Test Methods}

There is currently no infectious virus load for DENV in blood or plasma collected in Germany. Asymptomatic carriers with protective DENV antibodies are not infectious, therefore antibody testing is not required (see section 4.2). Tests for the detection of DENV (RNA-NAT or the less sensitive antigen test), and DENV antibodies (ELISA) are described in section 1.4. Even though the risk of transmission of imported DENV infections can almost entirely be ruled out linked to the above described donor referral for travellers, presence of DENV in imported plasma for fractionation cannot be ruled out. Testing for DENV, however, is not required, since the inactivation procedures should be also effective against DENV.

\subsection{Methods for Removal and Inactivation of the Infectious Agent}

DENV could be completely removed or inactivated from spiked plasma by protein fractionation and subsequent inacti- vation by pasteurisation or solvent detergent treatment [114]. If the individual steps of the methods are added on to each other, a cumulative reduction factor for DENV-2 can be reached of more than $10 \log _{10}$ for albumin, and of more than $14 \log _{10}$ for an immunoglobulin product. With regard to inactivation, DENV behaves like other enveloped viruses. Due to the request that products from plasma must undergo at least 1 virus inactivation step during the manufacturing procedure, there is no risk of DENV transmission for these products, even if the starting material should contain a high viral burden.

\subsection{Feasibility and Validation of Procedures for Removal/ Inactivation of the Infectious Agent}

Similar to other flaviviruses, DENV has been rated as biosafety level 3. Work with DENV must be carried out using the appropriate safety preconditions [115]. So far, only DENV infections transmitted by percutaneous, but not aerogenous exposure have been described. Since DENV can be replicated in different cultured cells from humans and monkeys, for example Vero cells, a sufficient amount of virus can be manufactured to spike intermediate steps in the manufacture of blood products. Validation of the virus reduction could be performed using characterised DENV strains of all serotypes. Validation of DENV, however, is not required by the specification of the Committee for Medicinal Products for Human Use (CHMP) (Note for Guidance on Virus Validation Studies, CPMP/BWP/268/95), since the data for the inactivation of model viruses are equivalent [116].

\subsubsection{Inactivation}

DENV can be inactivated by pasteurisation and solventdetergent treatment [114]. DENV is also inactivated by methylene blue/light treatment [117]. No inactivation data are published for treatment with psoralen/amotosalen (Intercept ${ }^{\circledR}$, Cerus, Concord, CA, USA) and riboflavin. In plasma [118] and in platelet concentrates [119], WNV, a flavivirus which is very similar to DENV, is inactivated by treatment with amotosalen. Heat treatment of serum at $56{ }^{\circ} \mathrm{C}$ for $30 \mathrm{~min}$ inactivates $10^{6} \mathrm{pfu} / \mathrm{ml} \mathrm{WNV}$ completely [120]. A burden of WNVRNA was found in plasma from the USA, while it was absent in pools from Asia and Europe [119]; in conclusion, the burden of plasma pools with DENV should be low.

\section{Assessment}

DENV causes yearly around 50-100 million infections worldwide, of which around 500,000 lead to hospitalisations. DENV is thus the most frequent arbovirus infection transmissible to humans by mosquitoes. Lower primates and possibly other animals constitute the animal reservoir for 
DENV. It is unlikely, that this zoonotic agent can be eradicated. Essentially, children and adolescents in tropical endemic areas, who do not yet possess sufficient immunity against the 4 DENV serotypes, are the human reservoir. In the case of insufficient immunity, DENV infection can lead to lethal DHF or DSS via immune enhancement. During primary infection, DENV is transmissible by blood for around 4-21 days following a mosquito bite. Specific antiviral treatment of the DENV infection or a vaccine are so far not available, even after DENV being accepted and addressed as a global problem [121]. The DENV genome is highly variable by mutation and recombination. DENV is able to replicate in primates at $37^{\circ} \mathrm{C}$ and in the Aedes mosquito at ambient temperature. Ae. aegypticus and Ae. albopictus are the most frequent vectors for the transmission of DENV. These mosquitoes have spread over the entire Mediterranean region and to Central Europe. A human reservoir which would initiate the urban cycle for DENV does so far not exist in Central Europe. Apart from 3 cases in the year 2010, no autochthonous transmissions have been reported from South and Central Europe. Epidemiological studies should be performed to record the imported DENV infections in Germany, as well as surveillance whether autochthonous infections are occurring in Germany in view of a continued change in climate and spread of the vector. No additional action is currently required to prevent a possible DENV transmission by blood transfusion, beyond the mandatory requirement to defer donors for 4 weeks following febrile disease and for 6 months following a stay in a malaria-endemic region.

This paper was completed on November 24, 2010, and approved by the German Advisory Committee Blood (Arbeitskreis Blut) on March 21, 2011. It was compiled by the members of the subgroup 'Assessment of Pathogens Transmissible by Blood' of the German Advisory Committee Blood (Arbeitskreis Blut):

Note added in proof:

A review on the status of a DENV vaccine [122] and a further trial [123] have been published in 2011 .

Prof. Dr. Lutz Gürtler

Dr. Ursula Bauerfeind

Dr. Johannes Blümel

Prof. Dr. Reinhard Burger

Prof. Dr. Christian Drosten

Dr. Albrecht Gröner

Dr. Margarethe Heiden

Prof. Dr. Martin Hildebrandt

Prof. Dr. Dr. Bernd Jansen

Dr. Thomas Montag-Lessing

Dr. Ruth Offergeld

Prof. Dr. Georg Pauli

Prof. Dr. Rainer Seitz

Dr. Uwe Schlenkrich

Dr. Volkmar Schottstedt

Dr. Johanna Strobel

Dr. Hannelore Willkommen

\section{References}

$>1$ Blümel J, Burger R, Gerlich W, Gürtler L, Heiden M, Hitzler W, Jansen B, Klamm H, Lefèvre H, Löwer J, Ludwig WD, Montag-Lessing T, Offergeld R, Paessens A, Pauli G, Seitz R, Schlenkrich $\mathrm{U}$, Willkommen H: Arboviruses - viruses transmissible by arthropods. Transfus Med Hemother 2005; 32:24-32.

2 Gubler DJ: Dengue/dengue haemorrhagic fever: history and current status. Novartis Found Symp 2006;277:3-16.

3 Tsai TF, Vaughn DW, Solomon T: Flaviviruses (Yellow fever, Dengue, Dengue hemorrhagic fever, Japanese encephalitis, West Nile encephalitis, St Louis encephalitis, tick-borne encephalitis); in Mandell GL, Douglas DR, Bennett JE (eds): Principles and Practice of Infectious Diseases, 6th ed. Philadelphia, PA, Elsevier, 2005, pp. 1927-1950

4 Halstead SB: Dengue. Lancet 2007;370:1644-1652.

5 Boonpucknavig S, Vuttivitroj O, Boonpucknavig $\mathrm{V}$ : Infection of young adult mice with dengue virus type 2. Trans Roy Soc Trop Med Hyg 1981;75:647653.

6 Aquilar-Setien A, Romero-Almaraz ML, SanchezHernandez C, Figueroa R, Juarez-Palma LP, Garcia-Flores MM, Vazques-Salinas C, Salas-Rojas M, Hidalgo-Martinez AC, Pierle SA, Garcia-Estrada C, Ramos C: Dengue virus in Mexican bats. Epidemiol Infect 2008;136:1678-1683.

7 Wang E, Ni H, Xu R, Barrett AD, Watowich SJ, Gubler DJ, Weaver SC: Evolutionary relationships of endemic / epidemic and sylvatic dengue viruses. J Virol 2000;74:3227-3234.
8 Gubler DJ, Kuno G, Markoff L: Flaviviruses; in Knipe DM, Howley PM (eds): Fields Virology, 5th ed. Philadelphia, PA, Wolter and Kluwer, 2007, pp. 1156-1252.

9 Lindenbach BD, Thiel HJ, Rice CM: Flaviviridae: the viruses and their replication; in Knipe DM, Howley PM (eds): Fields Virology, 5th ed. Philadelphia, PA, Wolter and Kluwer, 2007, pp. 1101-1155.

10 Zhang Y, Corver J, Chipman PR, Zhang W, Pletnev SV, Sedlak D, Bakter TS, Strauss JH, Kuhn RJ, Rossmann MG: Structures of immature flavivirus particles. EMBO J 2003;22:2604-2613.

11 Smith TJ, Brandt WE, Swanson JL, McCrown JM, Buescher EL: Physical and biological properties of dengue-2 virus and associated antigens. J Virol 1970;5:524-532.

12 Gubler DJ, Rosen L: Quantitative aspects of replication of dengue viruses in Aedes albopictus (Diptera: Culicidae) after oral and parenteral infection. J Med Entomol 1977;13:469-472.

13 Leitmeyer KC, Vaughn DW, Watts DM, Salas R, Villalobos I, de Chacon, Ramos C, Rico-Hesse R: Dengue virus structural differences that correlate with pathogenesis. J Virol 1999;73:4738-4747.

14 Pokidysheva E, ZhangY, Battisti AJ, Bator-Kelly CM, Chipman PR; Xiao C, Gregorio GG, Hendrickson WA, Kuhn RJ, Rossmann MG: Cryo-EM reconstruction of dengue virus in complex with the carbohydrate recognition domain of DC-SIGN. Cell 2006;124:485-493.
15 Chen Y, Maguire T, Hileman RE, Fromm JR, Esko JD, Linhardt RJ, Marks RM: Dengue virus infectivity depends on envelope protein binding to target cell heparan sulfate. Nat Med 1997;3:866-871.

16 Lee E, Lobigs M: Substitutions at the putative receptor-binding site of an encephalitic flavivirus alter virulence and host cell tropism and reveal a role for glycosaminoglycans in entry. J Virol 2000;74:8867-8875.

17 Jindadamrongwech S, Thepparit C, Smith DR: Identification of GRP 78 (BiP) as a liver cell expressed receptor element for dengue virus serotype 2. Arch Virol 2004;149:915-927.

18 Littaua R, Kurane I, Ennis FA: Human IgG Fc receptor II mediates antibody-dependent enhancement of dengue virus infection. J Immunol 1990; 144:3183-3186.

19 Koschinski A, Wengler G, Wengler G, Reep H: The membrane proteins of flaviviruses from ionpermeable pores in the target membrane after fusion: identification of the pores and analysis of their possible role in virus infection. J Gen Virol 2003; 84:1711-1721.

20 Reyes-del Valle J, Chávez-Salinas S, Medina F, Del Angel RM: Heat shock protein 90 and heat shock protein 70 are components of dengue virus receptor complex in human cells. J Virol 2005;79:4557-4567.

21 Welsch S, Miller S, Romero-Brey I, Merz A, Bleck CK, Walther P, Fuller SD, Antony C, KrijnseLocker J, Bartenschlager R: Composition and three-dimensional architecture of the dengue virus replication and assembly sites. Cell Host Microbe 2009;5:365-375. 
22 Benarroch D, Egloff MP, Mulard L, Guerreiro C, Romette JL, Canard B: A structural basis for the inhibition of the NS5 dengue virus mRNA 2'Omethyltransferase domain by ribavirin 5'-triphosphate. J Biol Chem 2004;279:35638-35643.

23 Zhou Y, Ray D, Zhao Y, Dong H, Ren S, Li Z, Guo Y, Bernard KA, Shi PY, Li H: Structure and function of flavivirus NS5 methyltransferase. J Virol 2007;81:3891-3903.

24 Guilarde AO, Turchi MD, Siqueira JB Jr, Feres VC, Rocha B, Levi JE, Souza VA, Boas LS, Pannuti CS, Martelli CM: Dengue and dengue hemorrhagic fever among adults: clinical outcomes related to viremia, serotypes, and antibody response. J Infect Dis 2008;197:817-824.

-25 Su DH, Bacsal K, Chee SP, Flores JV, Lim WK, Cheng BC, Jap AH: Prevalence of dengue maculopathy in patients hospitalized for dengue fever. Opthalmology 2007;114:1743-1747.

26 Domingues RB, Kuster GW, Onuki-Castro FL, Souza VA, Levi JE, Pannuti CS: Involvement of the central nervous system in patients with dengue virus infection. J Neurol Sci 2008;267:36-40.

-27 Pecorari M, Longo G, Gennari W, Grottola A, Sabbatini A, Tagliazucchi S, Savini G, Monaco F, Simone M, Lelli R, Rumpianesi F: First human case of Usutu virus neuroinvasive infection, Italy, August-September 2009. Euro Surveill 2009;14. pii: 19446

28 Peters CJ. Infections caused by arthropod- and rodent-borne viruses; in Harrison (ed): Principles of Internal Medicine, 17th ed. New York, NY, McGraw Hill Medical, 2008, pp. 1226-1239.

29 Dejnirattisai W, Jumnainsong A, Onsirisakul N, Fitton P, Vasanawathana S, Limpitikul W, Puttikhunt C, Edwaards C, Duangchinda T, Supasa S, Chawansuntati K, Malasit P, Mogkolsapaya J, Screaton G: Cross-reacting antibodies enhance dengue virus infection in humans. Science 2010; 328:745-748.

-30 Scott RM, Nisalak A, Eckels KH, Tingpalapong M, Harrison VR, Gould DJ, Chapple FE, Russel PK Dengue-2 vaccine: viremia and immune responses in rhesus monkeys. Infect Immun 1980;27:181-186.

31 Haas W, Krause G, Marcus U, Stark K, Ammon A, Burger R: Emerging infectious diseases - Dengue-fever, West-Nile-fever, SARS, avian influenza, HIV. Internist (Berlin) 2004:45:684-692.

32 Sabin AB: Research on dengue during World War II. Am J Trop Med Hyg 1952;1:30-50.

\$3 Zhang C, Mammen MP Jr, Chinnawirotpisan P, Klungthong C, Rodpradit P, Monkongdee P, Nimmannitya S, Kalayanarooj S, Holmes EC: Clade replacements in dengue virus serotypes 1 and 3 are associated with changing serotype prevalence. J Virol 2005;79:15123-15130.

>34 Wichmann O, Lauschke A, Frank C, Shu PY, Niedrig M, Huang JH, Stark K, Jelinek T: Dengue antibody prevalence in German travellers. Emerg Infect Dis 2005;11:762-765.

35 Settah SG, Vernazza PL, Morant R, Schultze D: Imported dengue fever in Switzerland - serological evidence for a hitherto unexpected high prevalence. Schweiz Med Wochenschr 1995;125:1673-1678.

36 Hossain MA, Khatun M, Arjumand F, Nislauk A, Breiman RF: Serologic evidence of dengue infection before onset of epidemic, Bangladesh. Emerg Infect Dis 2003;9:1411-1414.

37 Hemmer CJ, Frimmel S, Kinzelbach R, Gürtler L, Reisinger EC: Global warming: trailblazer for tropical infections in Germany? Dtsch Med Wochenschr 2007;132:2583-2589.
Roiz D, Eritja R, Molina R, Melero-Alcibar R, Lucientes J: Initial distribution assessment of Aedes albopictus (Diptera: Culicidae) in the Barcelona, Spain, area. J Med Entomol 2008;45:347-352.

39 Ponçon N, Toty C, L'ambert G, le Goff G, Brengues C, Schaffner F, Fontenille D: Population dynamics of pest mosquitoes and potential malaria and West Nile virus vectors in relation to climatic factors and human activities in the Camargue, France. Med Vet Entomol 2007;21:350-357.

40 Masetti A, Rivasi F, Bellini R: Mosquito-based survey for the detection of flaviviruses and filarial nematodes in Aedes albopictus and other anthropophilic mosquitoes collectes in northern Italy. New Microbiol 2008;31:457-465.

41 Rahamat-Langendoen JC, van Vliet JA, Reusken CB: Climate change influences the incidence of arthropod-borne diseases in the Netherlands. Ned Tijdschr Geneeskd 2008;152:863-868.

42 Scholte EJ, Dijkstra E, Blok H, De Vries A, Takken W, Hofhuis A, Koopmans M, De Boer A, Reusken CB: Accidental importation of the mosquito Aedes albopictus into the Netherlands: a survey of mosquito distribution and the presence of dengue virus. Med Vet Entomol 2008;22:352-358.

43 La Ruche G, Souarès Y, Armengaud A, PelouxPetiot $\mathrm{F}$, Delaunay $\mathrm{P}$, Desprès $\mathrm{P}$, Lenglet $\mathrm{A}$, Jourdain F, Leparc-Goffart I, Charlet F, Ollier L, Mantey K, Mollet T, FournierJP, Torrents R, Leitmeyer K, Hilairet P, Zeller H, Van Bortel W, Dejour-Salamanca D, Grandadam M, GastelluEtchegorry M: First two autochthonous dengue virus infections in metropolitan France, September 2010. Euro Surveill 2010;15. :pii: 19676. www.eurosurveillance.org/ViewArticle.aspx? ArticleId=19676.

44 Schmidt-Chanasit J, Haditsch M, Schöneberg I, Günther S, Stark K, Frank C: Dengue virus infection in a traveller returning from Croatia to Germany. Euro Surveill 2010;15. pii: 19677. www.eurosurveillance.org/ViewArticle.aspx? ArticleId $=19677$.

45 Laferl H, Szell M, Bischof E, Wenisch C: Imported dengue fever in Austria 1990-2005. Travel Med Infect Dis 2006;4:319-323.

46 Tarantola A; Quatresous I, Ledrans M, Lassel L, Krastinova E, Cordel H, Lapidus N, Debruyne M, Poveda JD, Boude-Chevalier M, Schuffenecker I, Zeller H, Grandadam M, Tolou H, Paquet C: Imported cases of dengue fever diagnosed in metropolitan France, from January 2001 to December 2006. Med Mal Infect 2009;39:41-47.

47 Heddini A, Janzon R, Linde A: Increased number of dengue cases in Swedish travellers to Thailand. Euro Surveill 2009;14. pii: 19111.

48 Hunsperger EA, Yoksan S, Buchy P, Nguyen VC, Sekaran SD, Enria DA, Pelegrino JL, Vázquez S, Artsob H, Drebot M, Gubler DJ, Halstead SB, Guzmán MG, Margolis HS, Nathanson CM, Rizzo Lic NR, Besoff KE, Kliks S, Peeling RW: Evaluation of commercially available anti-dengue virus immunoglobulin M tests. Emerg Infect Dis 2009;15: 436-440.

49 Shanaka WW, Rodrigo I, Alcena DC, Rose RC, Jin X, Schlesinger JJ: An automated dengue virus microneutralization plaque assay performed in human $\mathrm{Fc}$ (gamma) receptor-expressing CV-1 cells Am J Trop Med Hyg 2009;80:61-65.

50 Lai CY, Tsai WY, Lin SR, Kao CL, Hu HP, King CC, Wu HC, Chang GJ, Wang WK: Antibodies to envelope glycoprotein of dengue virus during the natural course of infection are predominantly cross-reactive and recognize epitopes containing highly conserved residues at the fusion loop of domain II. J Virol 2008;82:6631-6643.
51 Sukupolvi-Petty S, Austin SK, Purtha WE, Oliphant T, Nybakken GE, Schlesinger JJ, Roehring JT, Gromowski GD, Barrett AD, Fremont DH, Diamond MS: Type- and subcomplex-specific neutralizing antibodies against domain III of dengue virus type 2 envelope protein recognize adjacent epitopes. J Virol 2007;81:12816-12826.

52 Chinnawirotpisan P, Mammen MP Jr, Nisalak A, Thaisomboonsuk B, Narupiti S, Thirawuth V, Putnak R, Zhang C: Detection of concurrent infection with multiple dengue virus serotypes in Thai children by ELISA and nested RT-PCR assay. Arch Virol 2008;153:2225-2232.

53 Matheus S, Meynard JB, Lavergne A, Girod R, Moua D, Labeau B, Dussart P, Lacoste V, Deparis $\mathrm{X}$ : Dengue-3 outbreak in Paraguay: investigations using capillary blood samples on filter paper. Am J Trop Med Hyg 2008;79:685-687.

54 Oceguera LF 3rd, Patiris PJ, Chiles RE, Busch MP, Tobler LH, Hanson CV: Flavivirus serology by Western blot analysis. Am J Trop Med Hyg 2007;77: 159-163.

55 Xu H, Di B, Pan YX, Qiu LW, Wang YD, Hao W, He LJ, Yuen KY, Che XY: Serotype 1-specific monoclonal antibody-based antigen capture immunoassay for detection of circulating nonstructural protein NS-1: Implications for early diagnosis and serotyping of dengue virus infections. J Clin Microbiol 2006;44:2872-2878.

56 Zainah S, Wahab AH, Mariam M, Fauziah MK, Khairul AH, Roslina I, Sairulakhma A, Kadimon SS, Jais MS, Chua KB: Performance of a commercial rapid dengue NS1 antigen immunochromatography test with reference to dengue NS-1 antigencapture ELISA. J Virol Methods 2009;155:157-160.

57 Lapphra K, Sanqcharaswichai A, Chokephaibulkit K, Tiengrim S, Piriyakarnsakul W, Chakorn T, Yoksan S, Wattanamonqkolsil L, Thamlikitkul V: Evaluation of an NS1 antigen detection for diagnosis of acute dengue infection in patients with acute febrile illness. Diagn Microbiol Infect Dis 2008;60:387-391.

58 Wang SM, Sekaran SD: Evaluation of a commercial SD dengue virus NS1 antigen capture enzymelinked immunosorbent assay kit for early diagnosis of dengue virus infection. J Clin Microbiol 2010;48: 2793-2797.

59 Lima Mda R, Nogueira RM, Schatzmayr HG, dos Santos FB: Comparison of three commercially available dengue NS1 antigen capture assays for acute diagnosis of dengue in Brazil. PLoS Negl Trop Dis 2010;4:e738.

60 Chanyasanha C, Hasebe F, Matias R, Igarashi A: Production of viral antigens in culture fluid of C6/36 mosquito cell line infected with dengue type 4 virus strains isolated from patients with different clinical severities. Acta Virol 1999;43:213-218.

61 Gleeson F, McBride J, Norton R: Culture-amplified detection of dengue virus from serum in an outbreak of dengue fever. J Med Virol 1999;57:212-215.

62 Zamree I, Drakes N, Rohani A, Lee HL: Sensitivity of Aedes albopictus C6/36 cells line for the detection and infectivity titration of dengue virus. Trop Biomed 2005;22:217-219.

63 Lee YR, Su CY, Chow NH, Lai WW, Lei HY, Chang CL, Chang TY, Chen SH, Lin YS, Yeh TM, Liu HS: Dengue viruses can infect human primary lung epithelia as well as lung carcinoma cells, and can also induce the secretion of IL-6 and RANTES. Virus Res 2007;126:216-225

64 Moreno-Altamirano MM, Sánchez-García FJ, Legorretta-Herera M, Aguilar-Carmona I: Susceptibility of mouse macrophage $\mathrm{J} 774$ to dengue virus infection. Intervirology 2007;50:237-239. 
65 Ekkapongpisit M, Wannatung T, Susantad T, Triwitayakorn K, Smith DR: c-DNA-ALFP analysis of differential gene expression in human hepatoma cells (HepG2) upon dengue virus infection. J Med Virol 2007;79: 552-561.

66 Liu CC, Lee SC, Butler M, Wu SC: High genetic stability of dengue virus propagated in MRC- 5 cells as compared to the virus propagated in vero cells. PLoS ONE 2008;19;3:e1810.

67 Das S, Pingle MR, Muñoz-Jordán J, Rundell MS, Rondini S, Granger K, Chang GJ, Kelly E, Spier EG, Larone D, Spitzer E, Barany F, Golightly LM: Detection and serotyping of dengue virus in serum samples by multiplex reverse transcriptase PCRligase detection reaction assay. J Clin Microbiol 2008;46:3276-3284.

68 Dumoulin A, Marti H, Panning M, Hatz C, Hirsch $\mathrm{HH}$ : Pan-dengue virus detection by PCR for travelers returning from the tropics. J Clin Microbiol 2008;46:3104-3106.

69 Kong YY, Thay CH, Tin TC, Devi S: Rapid detection, serotyping and quantitation of dengue viruses by TaqMan real-time one-step RT-PCR. J Virol Methods 2006;138:123-130.

70 Muñoz-Jordán JL, Collins CS, Verqne E, Santiago GA, Petersen L, Sun W, Linnen JM: Highly sensitive detection of dengue virus nucleic acid in samples from clinically ill patients. J Clin Microbiol 2009;47:927-931.

71 Gurukumar KR, Priyadarshini D, Patil JA, Bhagat A, Singh A, Shah PS, Cecilia D: Development of real time PCR for detection and quantitation of Dengue viruses. Virol J 2009;23:10.

72 Lanciotti RS, Calisher CH, Gubler DJ, Chang GJ, Vorndam AV: Rapid detection and typing of dengue viruses from clinical samples by using reverse transcriptase-polymerase chain reaction. J Clin Microbiol 1992;30:545-551.

73 Gomes AL, Silva AM, Cordeiro MT, Guimarães GF, Marques ET Jr, Abath FG: Single-tube nested PCR using immobilized internal primers for the identification of dengue virus serotypes. J Virol Methods 2007;145:76-79.

74 Klungthong C, Gibbons RV, Thaisomboonsuk B, Nisalak A, Kalayanarooj S, Thirawuth V, Nutkumhang N, Mammen MP Jr, Jarman RG: Dengue virus detection using whole blood for reverse transcriptase PCR and virus isolation. J Clin Microbiol 2007;45:2480-2485.

75 Grant-Klein RJ, Baldwin CD, Turell MJ, Rossi CA, Li F, Lovari R, Crowder CD, Matthews HE, Rounds MA, Eshoo MW, Blyn LB, Ecker DJ, Sampath R, Whitehouse CA: Rapid identification of vector-borne flaviviruses by mass spectrometry. Mol Cell Probes 2010;24:219-228.

76 Wang WK, Chen HL, Yang CF, Hsieh SC, Juan CC, Chang SM, Yu CC, Lin LH, Huang JH, King CC: Slower rates of clearance of viral load and virus-containing immune complexes in patients with dengue hemorrhagic fever. Clin Infect Dis 2006;43: 1023-1030.

77 Onlamoon N, Noisakran S, Hsiao HM, Duncan A, Villinger F, Ansari AA, Perng GC: Dengue virus-induced hemorrhage in a nonhuman primate model. Blood 2010;4:115:1823-1834

78 Bianco C: Dengue and Chikungunya viruses in blood donations: risks to blood supply? Transfusion 2008;48:1279-1281.

79 Linnen JM, Vinelli E, Sabino EC, Tobler LH, Hyland C, Lee TH, Kolk DP, Broulik AS, Collins CS, Lanciotti RS, Busch MP: Dengue viremia in blood donors from Honduras, Brazil, and Australia. Transfusion 2008;48:1355-1362.
80 Mohammed H, Linnen JM, Munoz-Jordan JL, Tomashek K, Forster G, Broulik AS, Petersen L, Stramer SL: Dengue virus in blood donations, Puerto Rico 2005. Transfusion 2008;48:1348-1354.

81 Petersen LR, Busch MP: Transfusion-transmitted arboviruses. Vox Sang 2010;98:495-503.

82 Collenberg E, Ouedraogo T, Ganamé J, Fickenscher H, Kynast-Wolf G, Becher H, Kouyaté B, Kräusslich HG, Sangaré L, Tebit DM: Seroprevalence in six different viruses among pregnant women and blood donors in rural and urban Burkina Faso: a comparative analysis. J Med Virol 2006;78:683-692.

83 Teichmann D, Göbels K, Niedrig M, Grobusch MP: Dengue virus infection in travellers returning to Berlin, Germany: clinical, laboratory and diagnostic aspects. Acta Trop 2004;90:87-95.

85 Allwinn R, Hofknecht N, Doerr HW: Dengue in travellers is still underestimated. Intervirology 2008;51:96-100.

85 Jelinek T, Mühlberger N, Harms G, Corachán M, Grobusch MP, Knobloch J, Bronner U, Laferl H, Kapaun A, Bisoffi Z, Clerinx J, Puente S, Fry G, Schulze M, Hellgren U, Gjørup I,, Chalupa P, Hatz C, Matteelli A, Schmid M, Nielsen LN, da Cunha S, Atouguia J, Myrvang B, Fleischer K: European Network on Imported Infectious Disease Surveillance. Epidemiology and clinical features of imported dengue fever in Europe: sentinel surveillance data from TropNetEurop. Clin Infect Dis 2002:35:1047-1052.

86 Eisenhut M, Schwarz TF, Hegenscheid B: Seroprevalence of dengue, chikungunya and Sindbis virus infection in German aid workers. Infection 1999;27:82-85.

87 Murray K, Walker C, Herrington E, Lewis JA, McCormick J, Beasley DW, Tesh RB, Fisher-Hoch S: Persistent infection with West Nile virus years after initial infection. J Infect Dis 2010;201:2-4.

88 Dunstan RA, Seed CR, Keller AJ: Emerging viral threats to the Australian blood supply. Austr N Z J Public Health 2008;32:354-360.

89 Wichmann O, Gascon J, Schunk M, Puente S, Siikamaki H, Gjørup I, Lopez-Velez R, Clerinx J, Peyerl-Hoffmann G, Sundøy A, Genton B, Kern P, Galleri G, de Górgolas M, Mühlberger N, Jelinek $\mathrm{T}$ : Severe dengue virus infection in travelers: risk factors and laboratory indicators: J Infect Dis 2007; 195;1089-1096.

90 Chotmongkol V, Sawanyawisuth K: Case report: Dengue hemorrhagic fever with encephalopathy in an adult. Southeast Asian J Trop Med Public Health 2004;35:160-161.

91 Siqueira RC, Vitral NP, Campos WR, Oréfice F, de Moraes Figueiredo LT: Ocular manifestations in Dengue fever. Ocul Immunol Inflamm 2004;12:323327.

92 Finsterer J, Kongchan K: Severe persisting steroidresponsive Dengue myositis. J Clin Virol 2006;35: 426-428.

93 Chang J, Wang L, Ma D, Qu X, Guo H, Xu X, Mason PM, Bourne N, Moriarty R, Gu B, Guo TJ, Block TM: Novel imino sugar derivatives demonstrate potent antiviral activity against flaviviruses. Antimicrob Agents Chemother 2009;53: 1501-1508.

94 Rees CR, Costin JM, Fink RC, McMichael M, Fontaine KA, Isern S, Michael SF: In vitro inhibition of dengue virus entry by p-sulfoxy-cinnamic acid and structurally related combinatorial chemistries. Antiviral Res 2008;80:135-142.
95 Lescar J, Luo D, Xu T, Sampath A, Lim SP, Canard B, Vasudevan SG: Towards the design of antiviral inhibitors against flaviviruses: the case for the multifunctional NS3 protein from dengue virus as a target. Antiviral Res 2008;80:94-101.

96 Kyle JL, Balsitis SJ, Zhang L, Beatty PR, Harris E: Antibodies play a greater role than immune cells in heterologous protection against secondary dengue virus infection in a mouse model. Virology 2008;380:296-303.

97 Lisova O, Hardy F, Petit V, Bedouelle H: Mapping to completeness and transplantation of a group-specific, discontinuous, neutralizing epitope in the envelope protein of dengue virus. J Gen Virol 2007;88:2387-2397.

98 Goncalvez AP, Engle RE, St Claire M, Purcell RH, Lai CJ: Monoclonal antibody-mediated enhancement of dengue virus infection in vitro and in vivo and strategies for prevention. Proc Natl Acad Sci U S A 2007;104:9422-9427.

99 Wilder-Smith A, Deen JL: Dengue vaccines for travelers. Expert Rev Vaccines 2008;7:569-578.

100 Raviprakash K, Wang D, Ewing D, Holman DH, Block K, Woraratanadham J, Chen L, Hayes C, Dong JY, Porter K: A tetravalent dengue vaccine based on a complex adenovirus vector provides significant protection in rhesus monkeys against all four serotypes of dengue virus. J Virol 2008;82:6927-6934.

101 Sun W, Nisalak A, Gettayacamin M, Eckels KH Putnak JR, Vaughn DW, Innis BL, Thomas SJ, Endy TP: Protection of Rhesus monkeys against dengue virus challenge after tetravalent live attenuated dengue virus vaccination. J Infect Dis 2006; 193:1658-1665.

102 Zhou H, Deem MW: Sculpting the immunological response to dengue fever by polytopic vaccination. Vaccine 2006;24:2451-2459.

103 Blaney JE, Matro JM, Murphy BR, Whitehead SS: Recombinant, live-attenuated tetravalent dengue virus vaccine formulations induce a balanced, broad, and protective neutralizing antibody response against each of the four serotypes in rhesus monkeys. J Virol 2005;79:5516-5528.

104 Costa SM, Freire MS, Alves AM: DNA vaccine against the non-structural 1 protein (NS1) of dengue 2 virus. Vaccine 2006;24:4562-4564.

105 Widmann DG, Frolov I, Mason PW: Third-generation flavivirus vaccines based on single-cycle, encapsidation-defective viruses. Adv Virus Res 2008;72:77-126.

106 Clements DE, Coller BA, Lieberman MM, Ogata S, Wang G, Harada KE, Putnak JR, McDonell M, Bignami GS, Peters ID, Leung J, Weeks-Levy C, Nakano ET, Humphreys T: Development of a recombinant tetravalent dengue virus vaccine: immunogenicity and efficacy studies in mice and monkeys. Vaccine 2010;28:2705-2715.

107 Tambyah PA, Koay ES, Poon ML, Lin RV, Ong BK; Transfusion-Transmitted Dengue Infection Study Group: Dengue haemorrhagic fever transmitted by blood transfusion. N Engl J Med 2008; 359:1526-1527.

108 Chuang VW, Wong TY, Leung YH, Ma ES, Law YL, Tsang OT, Chan KM, Tsang IH, Que TL, Yung RW, Liu SH: Review on Dengue fever cases in Hong Kong during 1998 to 2005. Hong Kong Med J 2008;14:170-177.

109 Tan FL, Loh DL, Prabhakaran K, Tambyah PA Yap HK: Dengue haemorrhagic fever after living donor renal transplantation. Nephrol Dial Transplant 2005;20:447-448. 
110 Hirsch JP, Deschamps C, Lhuillier M: Metropolitan transmission of dengue by accidental inoculation a a hospital. Ann Med Interne (Paris) 1990;141:629.

111 De Wazières B, Gil H, Vuitton DA, Dupon JL: Nosocomial transmission of dengue from a needlestick injury. Lancet 1998;351:498.

112 Langgartner J, Audebert F, Schölmerich J, Glück T: Dengue virus infection transmitted by needle stick injury. J Infect 2002;44:269-270.

113 Wagner D, de With K, Huzly D, Hufert F, Weidmann M, Breisinger S, Eppinger S, Kern WV Bauer TM: Nosocomial acquisition of dengue. Emerg Infect Dis 2004;10:1872-1873.

114 Xie YW, Chan PK, Szeto CK, Kwok SY, Chu IM, Chu SS, Cheung JL, Wong SW, Ail MB, Wong BL: Clearance of dengue virus in the plasma-derived therapeutic proteins. Transfusion 2008;48:13421347.

115 BG Merkblatt: Berufsgenossenschaft Chemie, Merkblatt 004. Heidelberg, Jedermann Verlag, 1998
116 Willkommen H, Löwer J: Theoretical considerations on viral inactivation or elimination. Dev Biol Stand 1993;81:109-116.

117 Huang Q, Fu WL, Chen B, Huang JF, Zhang X, Xue Q: Inactivation of dengue virus by methylene blue/narrow bandwidth light system. J Photochem Photobiol B 2004;77:39-43.

118 Singh Y, Sawyer LS, Pinkoski LS, Dupuis KW, Hsu JC, Lin L, Corash L: Photochemical treatment of plasma with amotosalen and long-wavelength ultraviolet light inactivates pathogens while retaining coagulation function. Transfusion 2006;46:1168-1177.

9 Gallian P, Vignoli C, Dombey AM, Mayaudon V, Lin L, Galichet V, Cantaloube JF, De Micco P: Inactivation of a European strain of West Nile virus in single- donor platelet concentrate using the INTERCEPT blood system. Vox Sang 2006; 91:345-347.
20 Fang Y, Brault AC, Reisen WK: Comparative thermostability of West Nile, St. Louis encephalitis, and western equine encephalomyelitis viruses during heat inactivation for serologic diagnostics. Am J Trop Med Hyg 2009;80:862-863.

121 Pfleiderer C, Blümel J, Schmidt M, Roth WK, Houfar MK, Eckert J, Chudy M, Menichetti E, Lechner S, Nübling CM: West Nile virus and blood product safety in Germany. J Med Virol 2008;80:557-563.

122 Thomas SJ: The necessity and quandaries of Dengue vaccine development. JID 2011;203:299-303.

123 Durbin AP, Schmidt A, Elwwod D, Wanionek KA, Lovchick J, Thumar Bhavin, Murphy BR, Whitehead SS: Heterotypic dengue infection with live attenuated montypic dengue virus vaccines: implications for vaccination of populations in areas where dengue is endemic. J Infect Dis 2011 203:327-334. 